\title{
Spatial Analysis of Soil Fertility in a Part of Nalgonda District, Andhra Pradesh, India
}

\author{
K. Brindha ${ }^{1,2}$ and L. Elango ${ }^{2 *}$ \\ ${ }^{1}$ International Water Management Institute, Vientiane, Lao PDR \\ ${ }^{2}$ Department of Geology, Anna University, Chennai- 600025, India \\ *Email: elango@annauniv.edu; elango34@hotmail.com
}

\begin{abstract}
Soil fertility was analysed in an agricultural area which forms a part of Nalgonda district, Andhra Pradesh, India. Soil samples were collected from 102 locations and analysed for various parameters such as $\mathrm{pH}$, EC, ORP, soil texture, calcium, magnesium, sodium, potassium, sulphate, calcium carbonate, CEC and base saturation percentage. High concentration of ions such as magnesium, sodium and potassium was observed in this area. Calcium and sulphate were deficient; calcium carbonate was low; CEC and base saturation percentage were very high in soil samples. Overall the fertility of soil was low with calcium and sulphate ions and high with the content of other parameters. This study will help to choose the type of crop that would be suitable for plantation in this area. Also, the composition of agrochemicals that will be required for this area can also be decided. This study serves as baseline information to improve the soil fertility in this intensively irrigated area.
\end{abstract}

Keywords: agrochemicals; base saturation percentage; cation exchange capacity; soil EC; soil fertility.

\section{Introduction}

India ranks second largest in farm output in the world. Agriculture is the major occupation in many parts of the country. More than $58 \%$ of the total population in India depends on agriculture as the principal source of livelihood (Department of Agriculture and Cooperation, 2011) and about 52\% of the rural population depends on agriculture for employment. One of the main states that contribute to the agricultural economy of India is Andhra Pradesh. Soil quality is an important criterion in agriculture. It is one of the key factors affecting plant growth. The quality of soil may be affected due to human activities such as improper land use and land management practices. Maximum productivity in agriculture depends on several factors such as soil composition, quantity of rainfall, type and amount of fertiliser applied etc. Knowledge on the spatial variation in soil parameters will form an input to various sectors such as soil science, agriculture and horticulture. This will in turn help to decide on the type of crop to be planted and fertiliser to be applied depending on the deficiency of a particular nutrient in soil.

A research project sponsored by Board of Research in Nuclear Sciences (BRNS), Department of Atomic Energy, Government of India was carried out in a part of Nalgonda district, Andhra Pradesh, India from March 2008 to January 2010. As a part of this project extensive studies were carried out on groundwater quality and modelling (Brindha and Elango, 2013; Brindha, 2012; Brindha and Elango, 2012; Elango et al., 2012; Rajesh et al., 2012; Brindha et al., 2011a,b; Brindha et al., 2010; Brindha and Elango, 2010). However, 
there have been no previous reports on the soil quality of this area even though agriculture is the major land use. Hence, this study will form as a baseline study to document and understand the spatial variation in various soil parameters in a part of Nalgonda district.

\section{Study area:}

\section{Materials and Methods}

This study was carried out in an intensively irrigated area which forms a part of Nalgonda district (Fig. 1). It is situated at a distance of $80 \mathrm{~km}$ ESE of Hyderabad. An area of 724 sq km is considered for this study. There are two rivers namely Gudipalli Vagu which forms a part of the northern boundary and Pedda Vagu which forms the southern boundary of the study area. The Nagarjuna Sagar reservoir is present at the south eastern side of the study area.
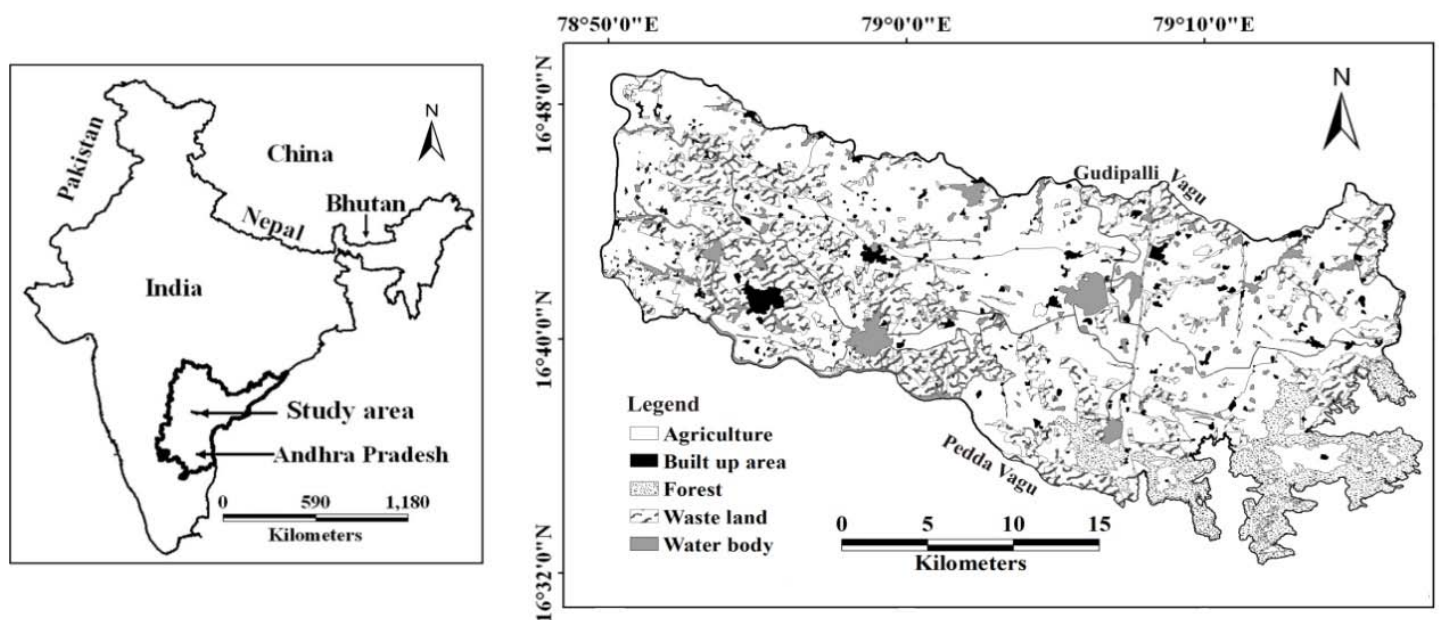

Fig. 1: Land use map with location of study area.

\section{Climate:}

This area experiences arid to semi-arid climate. Summer prevails from April to June with temperature ranging between $30^{\circ}$ and $46.5^{\circ} \mathrm{C}$. Winter prevails from November to January with temperature between $17^{\circ}$ and $38^{\circ} \mathrm{C}$. The average rainfall per year is about 600 mm which usually occurs in June-September during the southwest monsoon.

\section{Topography and drainage:}

Topographically the ground surface slopes towards southeast direction. This area has several small hillocks with height ranging from 250 to $300 \mathrm{~m}$. The depressed parts of the undulating topography of this area have numerous tanks and small reservoirs. The drainage pattern is dendritic to sub-dendritic. There are also few lined canal networks which cater for irrigation activity.

\section{Geology:}

Geology of the study area was derived from detailed field investigation, Geological Survey of India (GSI) maps of 1:50,000 scale (GSI 1995) and remote sensing data. This area lies in the northern part of the Cuddapah basin in southern India. Based on the geology, this 
region is mainly covered by granitic rocks which belong to late Archean and it primarily comprises of granite/granitic gneiss, pink biotite granite, grey hornblende biotite gneiss, migmatite granite and metabasalt. These rocks are generally medium to coarse grained. They are traversed by numerous dolerite dykes and quartz veins. Dolerite dykes cutting across the granites are found practically all over the area and are well exposed in most parts of the area. The Srisailam formation, which is the youngest member of the Cuddapah Supergroup directly overlay the basement granite with a distinct unconformity. The quartzite of Srisailam formation is exposed in the southeastern part of the study area.

\section{Landuse:}

Landuse map of the area derived from the Indian Remote sensing Satellite Linear Imaging Self scanning Sensor IV (IRS LISS IV) imagery (May 2007, January 2008 and April 2008; Mapping to 1:25,000) is given in Fig. 1. The forest cover in this area is thin to moderate. The major land use is for agriculture (Fig. 1). The crops grown in this area are sweet lime, castor, cotton, grams, groundnut and paddy. Rainfall is the major source of water for agriculture. Drip irrigation is practiced in this area especially for sweet lime. The majority of the households in the study area earn their livelihood from sources like agriculture and its allied activities. The cropping pattern depends on the climatic conditions and availability of water sources. Rainfall is the major source of groundwater recharge, apart from irrigation returns. The recharge from rainfall can sometimes raise the water table elevation immediately, or as much as a month later. Irrigation mainly depends upon the groundwater in this area.

\section{Sampling:}

Soil samples were collected from 102 locations during July 2010 (Fig. 2). Care was taken to collect one representative sample every $10 \mathrm{~km}^{2}$. Also it was made sure that samples were collected from agricultural and non-agricultural areas. Further, before soil sampling there was no rainfall and hence it can be considered that the soil quality has not been affected. Soil sampling was carried out after removing the top soil up to ten centimeters. Samples were collected by coring using a non-corrosive stainless steel corer to a depth of $30 \mathrm{~cm}$. The samples were stored in polyethylene bags and appropriately labeled. Care was taken to keep the samples away from heat to avoid alteration in soil characteristics.

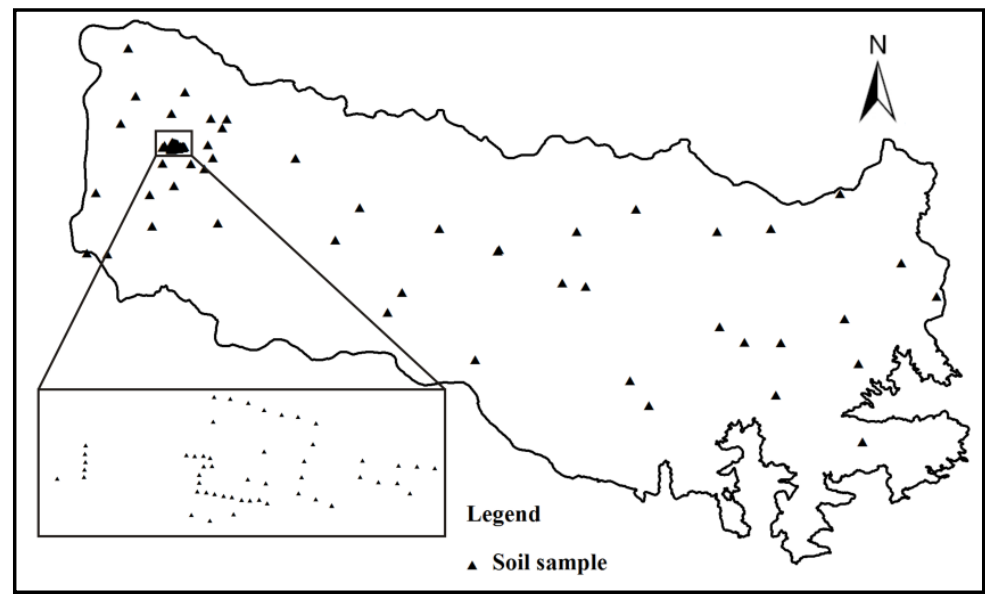

Fig. 2: Location of soil samples. 


\section{Analysis:}

A total of 102 soil samples from different locations, representing different terrains were collected from the study area. The collected soil samples were analyzed for the various properties such as $\mathrm{pH}$, electrical conductivity (EC), oxidation reduction potential (ORP), texture (sand, silt and clay ratio), bulk density, particle density, porosity, hydraulic conductivity, calcium, magnesium, sodium, potassium, sulphate, calcium carbonate and cation exchange capacity (CEC).

Soil $\mathrm{pH}$ and ORP was determined by mixing a known weight of soil sample with water (ratio 1:1) (Kalra, 1995) and then measured using YSI multiparameter probe. Soil EC was determined by mixing water and soil which was allowed to stand for $30 \mathrm{~min}$ and then measured using conductivity electrode (Rhoades, 1996). Soil texture by means of percentage of sand, silt and clay present was determined using pipette method (Sheldrick and Wang, 1993).

Calcium and magnesium were extracted using neutral normal ammonium acetate and were determined by titration method (APHA, 1998). Sodium and potassium were also extracted using neutral normal ammonium acetate and then analyzed in flame photometer (Schollenberger and Simon, 1945). Sulphate was analyzed using 0.2M ammonium acetate $0.25 \mathrm{M}$ acetic acid extraction reagent and measured using UV-VIS Spectrophotometer at 420nm (Schulte and Eik, 1988). Calcium carbonate was determined by acidimetry method by using $1 \mathrm{~N} \mathrm{HCl}$ and $0.5 \mathrm{~N} \mathrm{NaOH}$ as titrant (Bashour and Sayegh, 2007). All the chemicals used were of analytical grade and was procured from Merck. CEC is determined by the summation of sodium, potassium, calcium, and magnesium ions and is represented in meq/100g of soil.

\section{Spatial interpolation:}

Arc GIS 9.3 was used to prepare spatial variation in concentration of different parameters by inverse distance weighted method. All the other maps were also prepared using this software.

\section{Results and Discussion}

The statistical summary of various parameters determined in soil which decides the fertility of soil is given in Table-1.

\section{Soil texture:}

Soil texture is determined by the distribution of sand, silt and clay particles in the soil. This is an important factor to determine the soil fertility as it influences the quantity of water that can be retained in soil, aeration and type of crop to be grown. For instance sandy soil cannot hold water for a longer time while clay soil can retain water for a longer period of time. The soil texture can be determined by plotting the sand, silt and clay ratio on a triangular plot which classifies the soil into twelve different textural classes (sand, loamy sand, sandy loam, loam, silt loam, silt, sandy clay loam, clay loam, silty clay loam, sandy clay, silty clay and clay). The dominant soil texture in this area is sand (Fig. 3). Many of the soil samples belong to loamy sand category but there are also few cases of sandy clayey loam. 
Table-1: Statistical summary of various parameters in soil.

\begin{tabular}{|c|c|c|c|c|}
\hline Parameter & Unit & Minimum & Maximum & Mean \\
\hline Sand & $\%$ & 37.3 & 93.6 & 76.2 \\
\hline Silt & $\%$ & 3.0 & 62.3 & 20.5 \\
\hline Clay & $\%$ & 0.2 & 42.8 & 3.2 \\
\hline $\mathrm{pH}$ & No unit & 5.2 & 8.8 & 7.4 \\
\hline $\mathrm{EC}$ & $\mathrm{mS} / \mathrm{cm}$ & 0.0 & 0.5 & 0.2 \\
\hline ORP & $\mathrm{mV}$ & 145.6 & 236.6 & 196.8 \\
\hline Calcium & $\mathrm{mg} / \mathrm{g}$ & 0.2 & 7.8 & 2.6 \\
\hline Magnesium & $\mathrm{mg} / \mathrm{g}$ & 0.0 & 6.5 & 1.4 \\
\hline Sodium & $\mathrm{mg} / \mathrm{g}$ & 0.0 & 19.0 & 7.4 \\
\hline Potassium & $\mathrm{mg} / \mathrm{g}$ & 0.3 & 11.8 & 3.1 \\
\hline Sulphate & $\mathrm{mg} / \mathrm{g}$ & 0.0 & 2.7 & 0.6 \\
\hline $\mathrm{CaCO}_{3}$ & $\%$ & 0.4 & 28.2 & 4.6 \\
\hline CEC & meq/100g & 5.8 & 139.0 & 64.7 \\
\hline
\end{tabular}

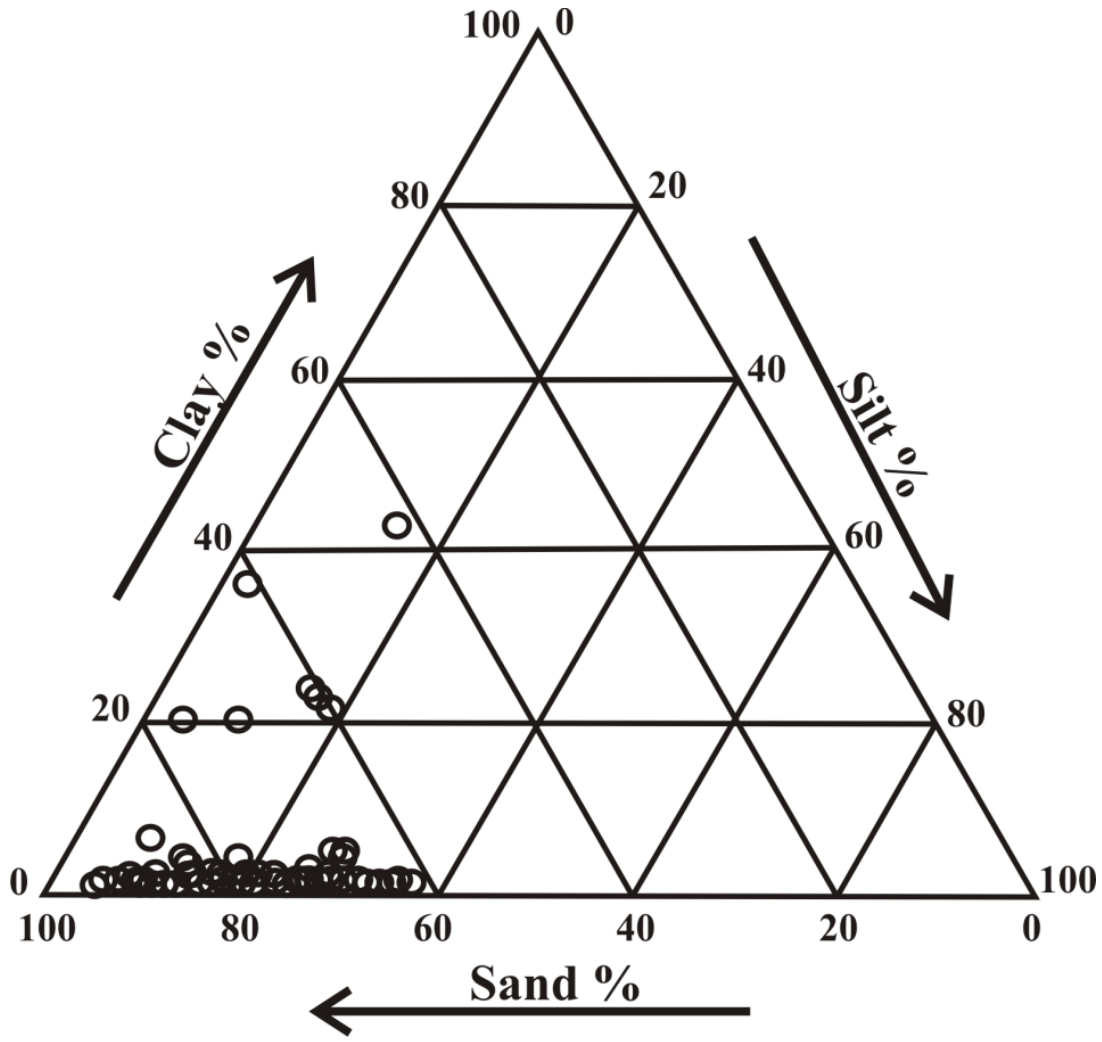

Fig. 3: Texture of soil in the study area. 
Table-2: Nature of soil based on $\mathrm{pH}$.

\begin{tabular}{|c|c|c|}
\hline pH range & Nature of soil & Number of soil \\
\hline \multicolumn{2}{|c|}{ Marx et al. (1999) } & samples \\
\hline Below 5.1 & Strongly acid & Nil \\
\hline 5.2 to 6 & Moderately acid & 4 \\
\hline 6.1 to 6.5 & Slightly acid & 6 \\
\hline 6.6 to 7.3 & Neutral & 27 \\
\hline 7.4 to 8.4 & Moderately alkaline & 63 \\
\hline above 8.5 & Strongly alkaline & 2 \\
\hline
\end{tabular}

pH:

This is the hydrogen ion activity occurring in the soil. The acidic or alkaline nature of soil determines the weathering/solubility of geologic minerals, availability of minerals and nutrients to plants and the microbial population in soil. Intensive agriculture in an area can alter the $\mathrm{pH}$ of the soil. The $\mathrm{pH}$ varying between 6 and 7.5 is optimal for plant growth (United States Department of Agriculture, 1999). In this area, $\mathrm{pH}$ varies from 5.2 to 8.8 with a mean of 7.4. Based on the different range of $\mathrm{pH}$ in soil, the nature of soil has been classified as given by Marx et al. (1999) in Table-2. The major factors affecting soil $\mathrm{pH}$ are temperature and rainfall, which control the intensity of leaching and soil mineral weathering (United States Department of Agriculture, 1999). Spatial variation in $\mathrm{pH}$ of the study area indicates that most of the area ranges from slightly acidic to slightly alkaline in nature (Fig. 4).

\section{EC and ORP:}

The EC represent the total amount of soluble salts that are present in the soil. The application of agrochemicals and intensive agriculture may affect the salt content in soil. Also due to excess evaporation and lesser rainfall the quantity of salts in soil may increase. These salts are essential for plant growth to some extent and may become harmful when in excess. EC of up to $0.8 \mathrm{mS} / \mathrm{cm}$ is acceptable for plant growth. The maximum EC measured in this area was $0.5 \mathrm{mS} / \mathrm{cm}$ and the spatial variation in EC of the study area show that most of the area has EC ranging between 0.1 to $0.2 \mathrm{mS} / \mathrm{cm}$ and is non saline (Fig. 4). Thus this area is not posing any hazard to soil fertility based on EC (Table-3).

Pitty (1979) put forth that the soil formation is determined in many ways by the character and intensity of oxidation reduction process. The ORP in soil has an impact on the solubility of ions in soil. The spatial variation in ORP (Fig. 4) shows that most of the study area varies from 200 to $220 \mathrm{mV}$ especially in the central parts of the study area.

\section{CEC and base saturation percentage:}

CEC is the ability of the soil to adsorb cations in exchangeable forms (Chesworth, 2008). It corresponds to the negative charge of the soil and is expressed in centimoles of positive charge per $\mathrm{kg}$ of soil (cmol/ $\mathrm{kg}$ ) or milliequivalents per $100 \mathrm{~g}$ of soil (meq/100g). CEC is also related to soil texture and if CEC levels above 20 or $25 \mathrm{meq} / 100 \mathrm{~g}$, the soil can hold many more nutrients than a plant would normally need in a year. The CEC of soil in most part of the study area is under very high category ( $>40 \mathrm{meq} / 100 \mathrm{~g}$ ) which is given in 
Table-4. Fig. 5 shows that most part of the area have CEC ranging between 75 meq/100g to $100 \mathrm{meq} / 100 \mathrm{~g}$.

Base saturation is the percentage of the CEC that is occupied by cations and it increases with $\mathrm{pH}$ which is calculated as given below (Jones, 2001).

$$
\text { Percent base saturation }=[(\mathrm{Ca}+\mathrm{Mg}+\mathrm{K}+\mathrm{Na}) / \mathrm{CEC}] \times 100
$$

Where all the concentration are expressed are in meq/100g. All the soil samples of this area except for one have a base saturation percentage of above 80 which is very high. The average percentage of base saturation was $93 \%$.

Table-3: Number of soil samples in different range of EC and their effects.

\begin{tabular}{|c|c|c|c|}
\hline $\begin{array}{c}2: 1 \\
\text { Water/soil } \\
(\mathrm{dS} / \mathbf{m} \text { or } \\
\mathrm{mS} / \mathrm{cm}) \\
\end{array}$ & $\begin{array}{l}\text { Nature of } \\
\text { soil }\end{array}$ & Effects & \multirow[t]{2}{*}{$\begin{array}{l}\text { Number of soil } \\
\text { samples }\end{array}$} \\
\hline \multicolumn{3}{|r|}{ Jones (2001) } & \\
\hline$<0.40$ & Non-saline & $\begin{array}{l}\text { Salinity effects mostly negligible, except } \\
\text { possibly beans and carrots }\end{array}$ & 95 \\
\hline $0.40-0.80$ & $\begin{array}{l}\text { Very } \\
\text { slightly } \\
\text { saline }\end{array}$ & $\begin{array}{l}\text { Yield of very salt-sensitive crops such as flax, } \\
\text { clovers (alsike, red), carrots, onions, bell } \\
\text { pepper, lettuce, and sweet potato may be } \\
\text { reduced by } 25 \text { to } 50 \%\end{array}$ & 7 \\
\hline $0.81-1.20$ & $\begin{array}{l}\text { Moderately } \\
\text { saline }\end{array}$ & $\begin{array}{l}\text { Yield of salt-sensitive crop restricted; } \\
\text { seedlings may be injured; satisfactory for } \\
\text { well-drained greenhouse soils; crop yields } \\
\text { reduced by } 25 \text { to } 50 \% \text { may include broccoli } \\
\text { and potato plus the other plants listed above }\end{array}$ & Nil \\
\hline $1.21-1.60$ & Saline soils & $\begin{array}{l}\text { Crops tolerant include cotton, alfalfa, cereals, } \\
\text { grain sorghum, sugar beets, bermuda grass, } \\
\text { tall wheat grass, and Harding grass; salinity } \\
\text { higher than desirable for greenhouse soils }\end{array}$ & Nil \\
\hline $1.61-3.20$ & $\begin{array}{l}\text { Strongly } \\
\text { saline }\end{array}$ & $\begin{array}{l}\text { Only salt-tolerant crops yield satisfactorily; } \\
\text { for greenhouse crops leach soil with enough } \\
\text { water so that } 2 \text { to } 4 \text { quarts }(2 \text { to } 4 \text { l) pass } \\
\text { through each square foot }(0.1 \mathrm{ml}) \text { of bench } \\
\text { area, or } 1 \text { pint of water }(0.5 \mathrm{~L}) \text { per } 6 \text {-in. (15- } \\
\text { cm) pot; repeat after } 1 \mathrm{~h} \text {; repeat again if } \\
\text { readings are still in the high range }\end{array}$ & Nil \\
\hline$>3.2$ & $\begin{array}{l}\text { Very } \\
\text { strongly } \\
\text { saline }\end{array}$ & $\begin{array}{l}\text { Only salt-tolerant grasses, herbaceous plants, } \\
\text { and certain shrubs and trees will grow }\end{array}$ & Nil \\
\hline
\end{tabular}



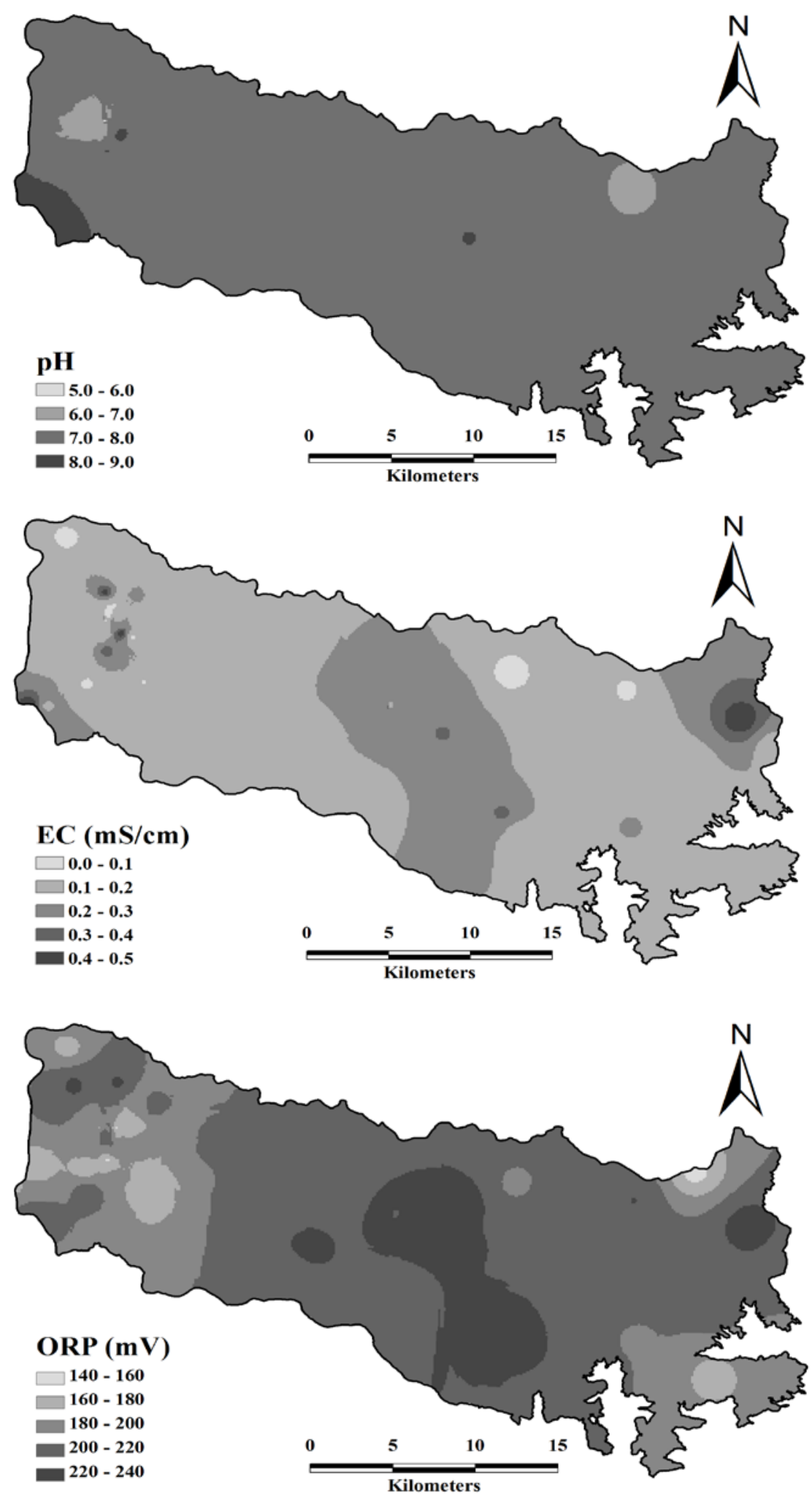

Fig. 4: Spatial variation in EC, $\mathrm{pH}$ and ORP in soil. 
Table-4: Ratings for CEC and base saturation percentage.

\begin{tabular}{|l|c|c|c|c|}
\hline \multirow{2}{*}{ Rating } & \multicolumn{2}{|c|}{ CEC (cmol/kg or meq/100g) } & \multicolumn{2}{c|}{ \% Base saturation } \\
\cline { 2 - 5 } & $\begin{array}{c}\text { Range } \\
\text { (Metson, 1961) }\end{array}$ & $\begin{array}{c}\text { Number of } \\
\text { samples }\end{array}$ & $\begin{array}{c}\text { Range } \\
\text { (Metson, 1961) }\end{array}$ & $\begin{array}{c}\text { Number of } \\
\text { samples }\end{array}$ \\
\hline Very low & $<6$ & 1 & $0-20$ & 0 \\
\hline Low & $6-12$ & 3 & $20-40$ & 0 \\
\hline Moderate & $12-25$ & 22 & $40-60$ & 0 \\
\hline High & $25-40$ & 9 & $60-80$ & 1 \\
\hline Very high & $>40$ & 67 & $>80$ & 101 \\
\hline
\end{tabular}

\section{Cations and anions:}

Calcium and magnesium in soil are mainly derived from weathering of geological materials and also from application of agrochemicals. It is important that the calcium and magnesium levels are balanced to ensure fertile soil. The $\mathrm{Ca} / \mathrm{Mg}$ ratio of soils indicates that the soil is either low or deficient in most of the locations (Table-5). It is also visible from Table-6 that calcium levels in soil are below the required level while magnesium is high. Spatial variation in calcium and magnesium are given in Fig. 6 where the concentration varies in small patches throughout the study area. Calcium carbonate is an another important characteristic of soil which is a measure of the total calcium and magnesium carbonate present in the soil as precipitated solid or crystal. The quality of soil based on calcium carbonate percentage are as: low (0-2.5\%) - 59 soil samples; moderate (2.5-5.0\%) - 16 soil samples; high (5.0-10\%) - 13 soil samples; very high (> 10\%) - 14 soil samples. The spatial variation in calcium carbonate percentage in soil is given in Fig. 5.

Table-5: $\mathrm{Ca} / \mathrm{Mg}$ ratio in soil samples.

\begin{tabular}{|c|c|c|}
\hline $\begin{array}{c}\text { Ca/Mg } \\
\text { ratio }\end{array}$ & Description & $\begin{array}{c}\text { Number of } \\
\text { samples }\end{array}$ \\
\cline { 1 - 2 } (Eckert, 1987) & \\
\hline$<1$ & Ca deficient & 64 \\
\hline $1-4$ & Ca (low) & 34 \\
\hline $4-6$ & Balanced & 3 \\
\hline $6-10$ & Mg (low) & 1 \\
\hline$>10$ & Mg deficient & 0 \\
\hline
\end{tabular}

Sodium is classified based on exchangeable sodium percentage (ESP) which is the percent of sodium in CEC. The minimum, maximum and mean ESP in soil were 1\%, 42.9\% and $14.9 \%$ respectively. Sixty three soil samples had ESP above $10 \%$ which is of concern as per Marx et al. (1999). Potassium is an important parameter of soil which is found to be very high (Table-6) while the concentration of sulphate is low (Table-7) in the soil of this area. Spatial variation in sodium, potassium and sulphate are given in Fig. 5 and Fig. 6. 

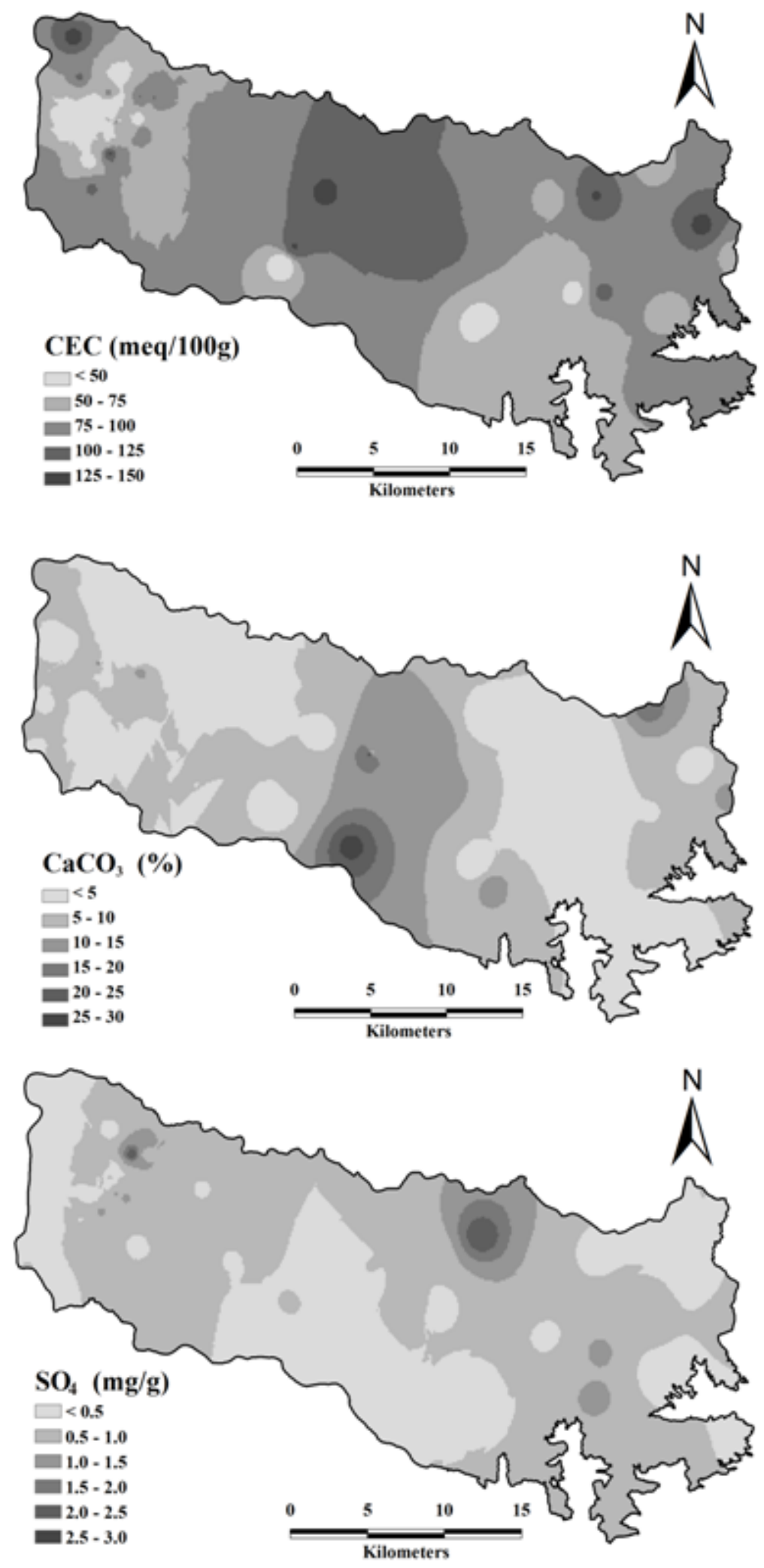

Fig. 5: Spatial variation in CEC, calcium carbonate and sulphate concentration in soil. 
Table-6: Levels of exchangeable cations (meq $/ 100 \mathrm{~g}$ or $\mathrm{cmol} / \mathrm{kg}$ ).

\begin{tabular}{|l|c|c|c|c|c|c|c|c|}
\hline \multirow{2}{*}{ Level } & \multicolumn{2}{|c|}{ Calcium } & \multicolumn{2}{c|}{ Magnesium } & \multicolumn{2}{c|}{ Sodium } & \multicolumn{2}{c|}{ Potassium } \\
\cline { 2 - 9 } & $\begin{array}{c}\text { Range } \\
\text { (Metson, } \\
\text { 1961) }\end{array}$ & $\begin{array}{c}\text { No. } \\
\text { samples }\end{array}$ & $\begin{array}{c}\text { Range } \\
\text { (Metson, } \\
\text { 1961) }\end{array}$ & $\begin{array}{c}\text { No. } \\
\text { samples }\end{array}$ & $\begin{array}{c}\text { Range } \\
\text { (Metson, } \\
\mathbf{1 9 6 1 )}\end{array}$ & $\begin{array}{c}\text { No. } \\
\text { samples }\end{array}$ & $\begin{array}{c}\text { Range } \\
\text { (Metson, } \\
\mathbf{1 9 6 1 )}\end{array}$ & $\begin{array}{c}\text { No. } \\
\text { samples }\end{array}$ \\
\hline Very low & $0-2$ & 19 & $0-0.3$ & 0 & $0-0.1$ & 0 & $0-0.2$ & 0 \\
\hline Low & $2-5$ & 30 & $0.3-1.0$ & 5 & $0.1-0.3$ & 1 & $0.2-0.3$ & 0 \\
\hline Moderate & $5-10$ & 31 & $1-3$ & 20 & $0.3-0.7$ & 1 & $0.3-0.7$ & 1 \\
\hline High & $10-20$ & 22 & $3-8$ & 36 & $0.7-2.0$ & 4 & $0.7-2.0$ & 12 \\
\hline $\begin{array}{l}\text { Very } \\
\text { high }\end{array}$ & $>20$ & 0 & $>8$ & 41 & $>2$ & 96 & $>2$ & 89 \\
\hline
\end{tabular}

Table-7: Classification of soil based on sulphate concentration.

\begin{tabular}{|c|c|c|}
\hline Level & Sulphate (ppm) & Number of samples \\
\hline \multicolumn{2}{|c|}{ Marx et al. (1999) } & \\
\hline Low & $<2$ & 99 \\
\hline Medium & $2-10$ & 3 \\
\hline sufficient & $>10$ & Nil \\
\hline
\end{tabular}
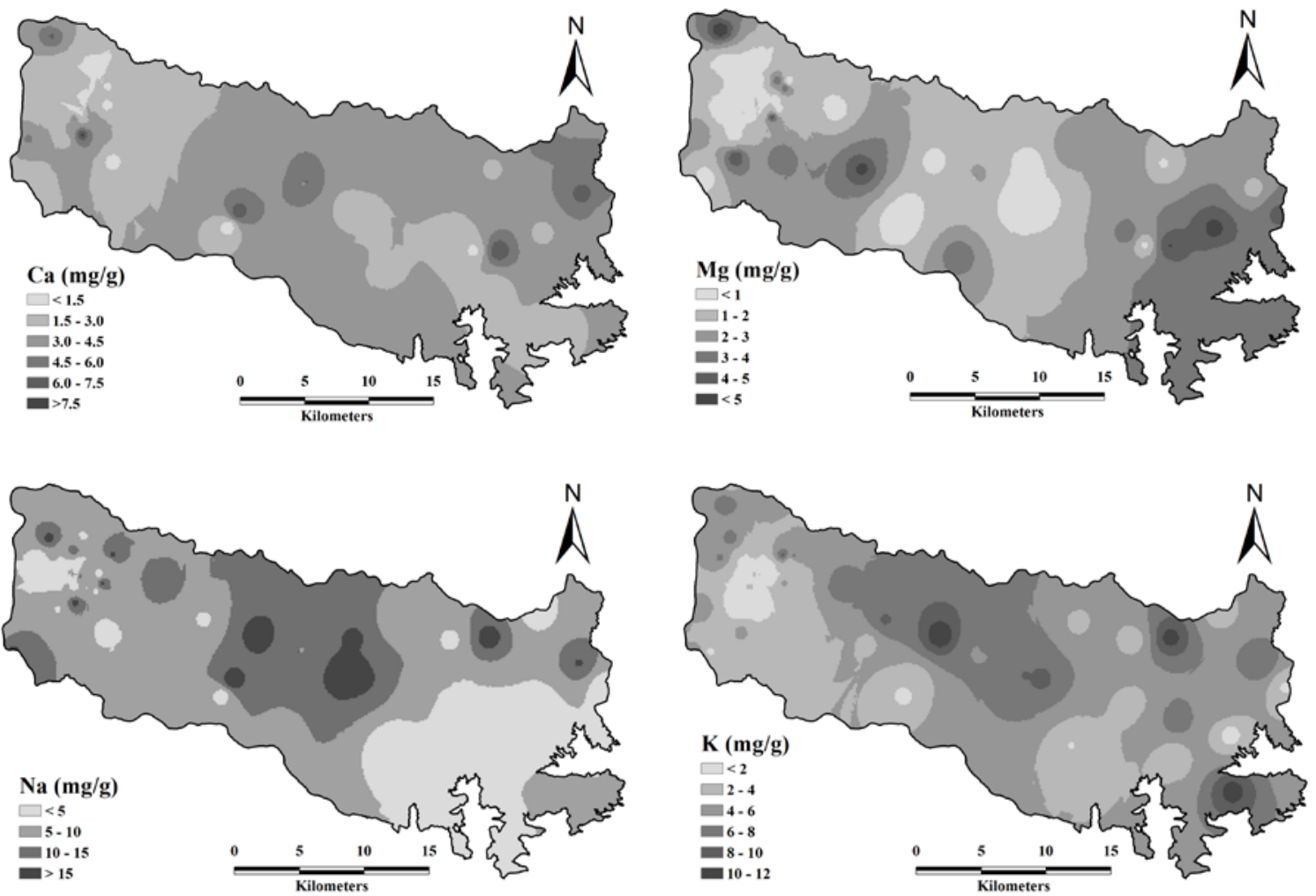

Fig. 6: Spatial variation in concentration of calcium, magnesium, sodium and potassium in soil. 


\section{Conclusion}

Soil fertility is an important criterion in agricultural regions. This study was carried out to understand the status of soil characteristics such as $\mathrm{pH}$, EC, ORP, soil texture, calcium, magnesium, sodium, potassium, sulphate, calcium carbonate, CEC and base saturation percentage in an intensively irrigated region forming a part of Nalgonda district, Andhra Pradesh, India. The soil is mostly neutral to alkaline based on $\mathrm{pH}$ and non saline based on EC. Calcium in soil is deficient based on $\mathrm{Ca} / \mathrm{Mg}$ ratio while magnesium, sodium, potassium and CEC are high in the soil of this area. Sulphate is found low in the soil. It is important to consider the results of this study while planning the agriculture development and management in this area. This study serves as a baseline data on the soil characteristics of this region.

Acknowledgements: The authors would like to acknowledge the Board of Research in Nuclear Sciences, Department of Atomic Energy, Government of India for funding this work (Grant no. 2007/36/35). Authors also like to thank the Department of Science and Technology's Funds for Improvement in Science and Technology scheme (Grant No. SR/FST/ESI-106/2010) and University Grants Commission’s Special Assistance Programme (Grant No. UGC DRS II F.550/10/DRS/2007(SAP-1)) for their support in creating laboratory facilities, which helped in carrying out part of this work. Thanks are due to Mr. T. Md. Zuhail, Research Fellow, Department of Geology, Anna University, India for carrying out analysis of soil samples.

\section{References}

APHA (1998) Standard methods for the examination of water and wastewater. 20th edn, American Public Health Association, Washington DC, USA.

Bashour, I. I. and Sayegh, A. H. (2007) Methods of analysis of soils of arid and semi-arid regions, Food and Agriculture Organization (FAO) of the United Nations.

Brindha, K. and Elango, L. (2010) Study on bromide in groundwater in parts of Nalgonda district, Andhra Pradesh. Earth Science India, v. 3(1), pp. 73-80.

Brindha, K. and Elango, L. (2012) Groundwater quality zonation in a shallow weathered rock aquifer using GIS. Geospatial Information Science, v. 15(2), pp. 95-104.

Brindha, K. and Elango, L. (2013) Occurrence of uranium in groundwater of a shallow granitic aquifer and its suitability for domestic use in southern India. J. Radioanalytical and Nuclear Chemistry, v. 295, pp. 357367.

Brindha, K. (2012) Assessment of fluoride and uranium in groundwater and hydrogeochemical modelling in a proposed uranium tailings pond area, southern India, Ph.D. thesis, Department of Geology, Anna University, India, 164 p.

Brindha, K., Elango, L. and Nair, R.N. (2011a) Spatial and temporal variation of uranium in a shallow weathered rock aquifer in southern India. J. Earth Systems Science, v. 120(5), pp. 911-920.

Brindha, K., Rajesh, R., Murugan, R. and Elango, L. (2010) Natural and anthropogenic influence on the fluoride and nitrate concentration of groundwater in parts of Nalgonda district, Andhra Pradesh, India. J. Applied Geochemistry, v. 12(2), pp. 231-241.

Brindha, K., Rajesh, R., Murugan, R. and Elango, L. (2011b) Fluoride contamination in groundwater in parts of Nalgonda district, Andhra Pradesh, India. Environmental Monitoring and Assessment, v. 172, pp. 481492.

Department of Agriculture and Cooperation (2011) Ministry of Agriculture, Government of India, Annual report 2010-2011, $197 \mathrm{p}$

Eckert D.J. (1987) Soil test interpretation: Base cation saturation ratios and sufficiency levels, In: J.R. Brown (Ed.) Soil testing: Sampling, correlation and interpretation, Soil Science Society of America, Spec. Pub. 21 SSSA Madison WI, pp. 53-64.

Elango, L., Brindha, K., Kalpana, L., Sunny, F., Nair, R.N. and Murugan, R. (2012) Groundwater flow and radionuclide decay-chain transport modelling around a proposed uranium tailings pond in India, Hydrogeology J., v. 20(4), pp. 797-812.

Chesworth, W. (2008) Encyclopedia of soil science, Springer, The Netherlands, 902 p. 
Open access e-Journal

Earth Science India, eISSN: $0974-8350$

Vol. 7 (I), January, 2014, pp. 36-48

http://www.earthscienceindia.info/

GSI (1995) Geological Survey of India’s Geology and minerals map of Nalgonda district, Andhra Pradesh, India.

Jones, J.B. Jr. (2001) Laboratory guide for conducting soil tests and plant analysis, CRC press, USA, 363 p.

Kalra, Y.P. (1995) Determination of pH of soils by different methods: collaborative study. J. Assoc. Off. Anal. Chem., v. 78, pp. 310-324.

Marx, E.S., Hart, J. and Stevens, R.G. (1999) Soil test interpretation guide. Oregon State University, pp. 1-8.

Metson, A.J. (1961) Methods of chemical analysis for soil survey sample, New Zealand, DSIR, Soil Bur. Bull., 12. GVT Printer Wellington, New Zealand, 208 p.

Pitty, A. F. (1979) Geography and soil properties, London: Methuen, 287 p.

Rajesh, R., Brindha, K., Murugan, R. and Elango, L. (2012) Influence of hydrogeochemical processes on temporal changes in groundwater quality in a part of Nalgonda district, Andhra Pradesh, India. Environmental Earth Sciences, v. 65, pp. 1203-1213.

Rhoades, J. D. (1996) Salinity: electrical conductivity and total dissolved solids, In: R.L. Sparks (Ed.) Methods for Soil Analysis, Part 3: Chemical Methods, Soil Science Society of America, Madison, pp. 417-435.

Schollenberger, C. J. and Simon R. H. (1945) Determination of exchange capacity and exchangeable bases in soil-ammonium acetate method, Soil Science, v. 59, pp. 13-24.

Schulte, E. E. and Eik, K. (1988) Recommended sulfate-sulfur test. In: W.C. Dahnke (Ed.) Recommended chemical soil test procedures. Publication Number 221 (revised), North Dakota State University, Fargo, pp. 17-19.

Sheldrick, B. H. and Wang, C. (1993) Particle size distribution. In: M.R. Carter (Ed.) Soil Sampling and Methods of Analysis, Lewis Publishers, pp. 499-511.

United States Department of Agriculture (1999) Agricultural Research Service, Natural Resources Conservation Service, Soil Quality Institute, 82 p.

(Received: 05.04.13 ; Accepted: 15.01.14) 